\title{
The Czech Republic through the eyes of Ukrainians
}

Streszczenie: W artykule zaprezentowano perspektywę Ukraińców mieszkających w Republice Czeskiej dotyczącą wybranych aspektów życia. Celem podjętych badań było ustalenie, jak Ukraińcy postrzegają życie w Republice Czeskiej, czeską kulturę i edukację, oraz co dostrzegają jako różnice i podobieństwa w obu kulturach i sposobach edukacji. Zwrócono uwagę, że badanie dotyczy subiektywnych doświadczeń, postaw i opinii indywidualnych respondentów. Dlatego, nie reprezentuje ono całej ukraińskiej mniejszości narodowej żyjącej w Republice Czeskiej.

Grupa badana składała się z dwóch grup respondentów o następującym składzie: pierwsza zawierała 8 respondentów Ukraińców na stałe mieszkających w Czechach ponad 10 lat, w drugiej grupie - wywiad przeprowadzono wśród 7 ukraińskich studentów, uczących się w Czechach, oraz wśród ich rodziców. W badaniu zastosowano podejście jakościowe, a dokładnie metodę półustrukturyzowanego wywiadu z respondentami. Analizę uzyskanych danych przeprowadzono za pomocą otwartego, a potem osiowego i selektywnego kodowania.

Słowa kluczowe: Ukraińcy, Republika Czeska, kultura, edukacja, edukacja międzykulturowa

\section{Introduction}

Who are the Ukrainians in the Czech Republic? They are primarily the largest national minority in the Czech Republic, with almost 132 thousand citizens of Ukraine (source: CZSO, to the date 31.12.2018). There are several different perspectives on Ukrainians in the Czech Republic. While part of the majority consider them to be immigrants who occupy jobs dedicated to Czechs. Others see seasonal workers who improve their unfavorable conditions in Ukraine by hard work for Czech construction companies. Another widespread opinion about Ukrainians in the Czech Republic pertains to their illegal activities and their application in the gray economy, which is only partly true. The fact is that many Ukrainians cover jobs that the local population 
is not interested in. However most of the Czech society takes an indifferent attitude towards Ukrainians.

The fact that Ukrainians long term and on the large-scale heading to the Czech Republic and settling in the Czech Republic gives us a chance to deeper understand this historically related, Slavic culture and find out in what we are similar and how the two societies differ. We have a chance to learn from each other what is better in each of the nations.

\section{Theory}

The text is based on theoretical concepts - migration, culture and education, which we define as follows. As the Ukrainians are actors in the migration phenomenon, we define this term together with Drbohlav (2015, p. 203), as "a broadly conditioned process that is often influenced by a complex of many internal and external factors." The primary aspect of migration is its distinction on voluntary migration, which is a conscious decision by a person to leave his country and involuntary, when there may be forced emigration. The vast majority of Ukrainian nationals certainly belong to the first group. In their case, it is the migration from internal motives, which, however, is strongly influenced by external factors.

By examining the question of why people migrate, there is a theory of migration dealing with so-called push and pull factors (Jansen and Lee, according to Uherek, 2004). While push factors force people to leave their country due to lack of jobs, poor economic conditions, war...), pull factors act in the opposite direction, thus attracting individuals to the target country, for example because of a higher standard of living, free health care, better education, higher earnings, etc.

In the research we observe two important subsystems of society, which are culture and education. According to the sociologists Montoussé and Renouard (2005, p. 106), culture is "a legacy of society... it is a complex whole that includes knowledge, faith, art, law, morality, customs and all other abilities and habits that a person adopts as a member of society". According to Nešpor (2017, no page), culture, among other things, manifests itself in "socio-cultural regulations (norms, values, cultural patterns) and in ideas." In the text, we are focusing on describing and comparing cultural patterns, mentalities, values, and ideas from the perspective of Ukrainians.

Another key concept is education, which is the sum of knowledge and skills, attitudes and values we gain during education. Its value and at the same 
time the goal according to Göbelová (2015) is the transfer of ideas between people and the ability of critical thinking. Educated people are less influential they see things in a context. Průcha (2003) states the education is a social value, but its significance depends on the role that education attributes to society for the life of an individual and for the development of society.

Thus, in the paper we summarize opinions, attitudes, view of Ukrainians on their lives as immigrants in the Czech Republic and on the life of Czech society. We have also compared the two cultures, mentality and education area with each other. The value of this contribution should be based on a better understanding of Ukrainian relations and their socio-cultural context.

\section{Methods}

The research was carried out within the framework of qualitative design, by means of in-depth interviews with respondents (Švaříček and Šed'ová, 2007). Subsequently, the data were analyzed in the form of open, axial and selective coding. The research sample consisted of two groups of respondents who had the following composition: The first group consisted of eight respondents of Ukrainians with permanent residence in the Czech Republic, living in the Czech Republic for more than ten years. Within the second group, we interviewed seven Ukrainian pupils ( $1^{\text {st }}-8^{\text {th }}$ year, 2nd year of grammar school), educating themselves in schools in the Czech Republic and their parents.

\section{Findings}

\subsection{Open coding}

Data analysis by open coding helps us discover certain topics and content that is hidden in text material. Data obtained during interviews with respondents we have assigned the appropriate codes, which we have merged according to their similarity into the following categories:

- reasons for the arrival of Ukrainians to the Czech Republic,

- life in the Czech Republic,

- relationship to the Czech Republic,

- mentality of Ukrainians and Czechs,

- Ukrainian and Czech culture,

- education in Ukraine and in the Czech Republic. 


\subsection{Axial coding}

In the next step, we proceeded to axial coding, which attempts to uncover interrelationships among categories by another arrangement (Strauss and Corbin, 1999).

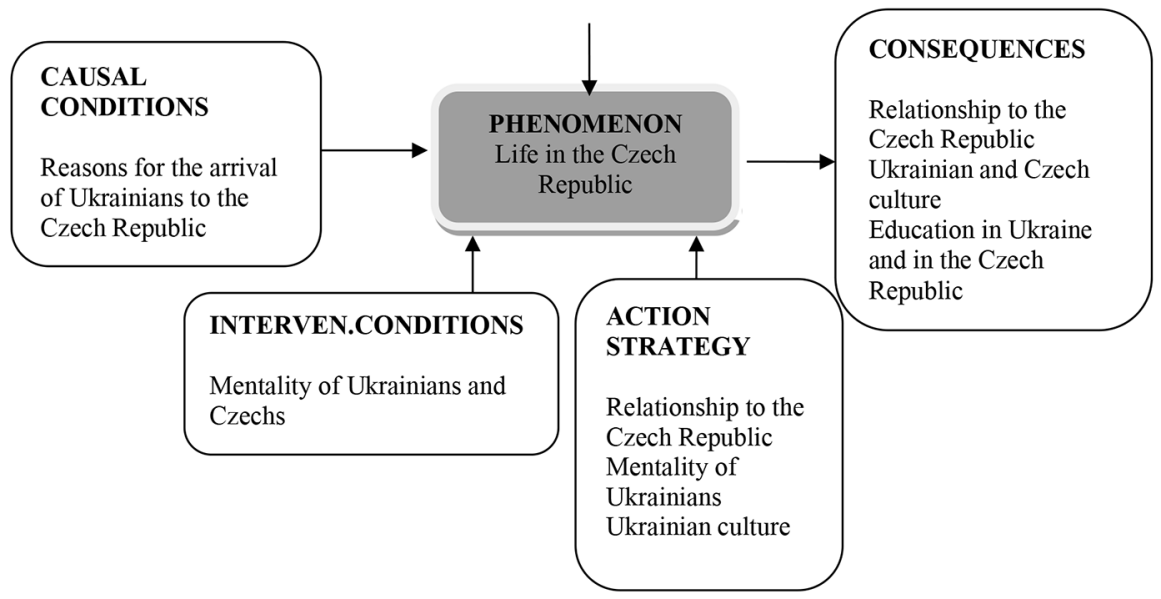

Source: own study.

\subsection{Selective coding}

\section{Close and yet unknown Czech Republic}

The Pull factor, or the main reason why the citizens of Ukraine choose the Czech Republic, is its cultural and linguistic affinity, partly due to the common history of the Czech state and western Ukraine in the period of Austria-Hungary in the first half of the $20^{\text {th }}$ century. Respondents often say that before their arrival they perceived Czechia as a dream country with a higher standard of living. Especially future immigrants from western Ukraine often learned about the Czech Republic from their relatives and acquaintances who had already visited the country or worked there. Compared to their lives in Ukraine, the worries that Czechs experience are often superficial than those in Ukraine because the Czech population is not facing so serious and existential problems. 
Next to the main reason for the resettlement of Ukrainians, a better standard of living, Ukrainians see the Czech Republic as a safe and cozy country where they can "hide" from their own troubled history and current, turbulent developments in their homeland. The Ukrainians wish and are looking for Ukraine's entry into the European Union and the Schengen area, and since it is still not in sight, they decide not only to emigrate to the Czechia, but also to stay there permanently.

\section{Unclear perspective of the life in Ukraine}

The most common push factor of Ukrainian migrants is the everyday uncertainty about what the near future brings and also modest standard of living in Ukraine. Ukrainian migrants perceive the political and difficult economic situation as particularly threatening regarding the lack of well-paid work, low pensions, expensive energy and housing. They are also concerns about the general mobilization of Ukrainians into the civil war in Ukraine.

Respondents interviewed, who have already resided in the Czech Republic and most of them gained Czech citizenship, migrated to Central Europe more than ten years ago, with the aim not only to find a job, but also to pay the study of their offspring at the Ukrainian University. If they did not do so immediately after their emigration, they moved their family to their new home over time to enable their children to study in the Czech Republic or abroad and to enable them to travel. The causes of which most respondents ultimately decided to stay in the destination country were simply the desire to have a job, a happy family and a better future for their children.

\section{Czech citizenship, yes or no?}

After years of residence in connection with the decision to settle in the Czech Republic permanently, most of them resolved to settle Czech citizenship. This step was led by both the desire to have as little troubles as possible with life in a foreign country and even more to merge with the majority. The progressive crisis in Ukraine and the disappointing hope of a possible return to Ukraine also had a great influence on the handling of Czech citizenship. Interviewees Ukrainians feel great disillusionment with the development of domestic politics, the economy and the military conflict between Ukraine and Russia. If they had previously considered returning to Ukraine, these hopes were rapidly disappearing due to the deteriorating situation in Ukraine. 
Czech citizenship has made life easier for Ukrainians by acting better and easier with the authorities, because not all officials looking at the Ukrainian passport and permanent residence card with confidence. Ukrainians, according to respondents, have a better effect on local residents with Czech citizenship, especially if they want to open a bank account or take out a loan.

\section{The Czech Republic is the second mom for me}

Ukrainian immigrants praise the Czech state and are grateful to them for the chance to live in peace, have a ordinary life. Most respondents at the beginning of their stay expected to have to overcome many barriers and did not expect to get anything for free. Persevere at work and trying to be diligent and honest Ukrainians perceive as a matter of honour that they advocate their country in front of Czech colleagues.

Regarding the relationship to both countries, the majority of respondents recognize Ukraine as their first home and states that they have two homes together with the Czech Republic. One respondent stated: "I have my mom and my husband's mom and the Czech Republic is the second mother for me". Respondents perceive the Czech Republic from the position of gratitude and respect, but emotionally the homeland remains home despite all their reservations about it.

\section{"When you're in a foreign cowshed, you have to bleat like the others" - the relationship between Ukrainians and Czechs}

To adapt to the new socio-cultural environment and society Ukrainian respondents considered as a matter of course. The cultural and mental proximity of the Czech nation made it easier for them to settle in without major problems. They declare that if they want to live in another country, it is the duty of each foreigner to adapt to the local customs and rules of the destination country. For Ukrainians that is not such difficult as for a culturally related nation. After many years in the Czech Republic, Ukrainians have established good relations with each other, but they declare that the Czechs have not always accepted Ukrainians without any problems.

Respondents pointed to one surviving stereotype and this is a different approach of Czechs to foreigners coming from the eastern and western parts of the world. While for foreigners from the West have a more open and understanding approach, attitude to foreigners coming from the East are more 
likely suspicious and distrustful. However, the attitude of the Czechs towards the Ukrainians in the case of settling Ukrainians in the Czech Republic usually turns into a friendly relationship.

The Czech nation is considered very cultivated by the Ukrainians. After the first contacts at the Czech authorities, the respondents were delighted with the pleasant and accommodating behaviour. Although later they evaluated that as superficial and without the genuine interest in the situation of the Ukrainians. At the same time, they noted that this mask of respectful behaviour is for foreigners necessary in contact with Czech officials to feel the acceptance of the majority. Respondents agree that the majority of their countrymen in Ukraine view the Czech Republic as a rich Western country with a high standard, which respondents, however, after a longer stay in the Czech Republic, consider to be quite average compared to other EU countries.

\section{Contact personally or indirectly?}

Long-term stay the respondents lead to a deeper reflection on the relations of Czechs and Ukrainians in the Czech Republic. Although all respondents evaluate mutual Czech-Ukrainian relations positively, several interesting differences were found.

Rather more restrained and respectful behaviour of Czechs compared to Ukrainians is considered a positive in official relations and as a negative in personal relations. They perceive it positive in relation to solving possible problems in various institutions, as they feel equal access to all people in that. Although respondents did not forget mention one thing about the way of contacting officials. If they wanted to deal with their affairs in Ukraine quickly and with a good result, they had to visit the officials personally, because the people there are not very willing to act mediated. Thus, in the Czech Republic, respondents met either with misunderstanding or with surprising views and smiles of officials who circumvented themselves. Often, officials were referred to the use of telephone and electronic connections.

\section{Calm and closed Czechs versus direct and opened Ukrainians}

Establishing relationships and personal contacts are initially perceived by Ukrainian respondents as problem-free, but if we go deeper, we come across subtle differences and nuances in the mentality of the representatives of both nations. Ukrainians consider Czechs cautious in behaving, they think longer before utters an opinion. Czechs are more accustomed to keeping their 
promises and more punctual. The Ukrainian temperament, which is more spontaneous and emotional compared to the Czech character, was aptly expressed by the respondent "every person is more open compared to Czech, and every nation is more open."

When we talk about mentality, Ukrainians perceive the Czechs tendency to be balanced, without conflict, which has its opposite in the Ukrainian nature. When we talk about mentality, Ukrainians perceive the Czechs tendency to be balanced, without conflict, which has its opposite in the Ukrainian nature. The Czech character is marked by the greater emphasis on compromises, adaptation, avoidance conflict, consideration and caution in judgments. While the Ukrainians more emphasis on individual freedom, selfassertion, on liberation from submission, openness, on sharpness in judgment and on sincerity. Ukrainians are also more open to foreigners. Due to the common historical heritage, when Czechs and Ukrainians lived under stronger nations and had to adapt to them, the Ukrainians can still feel like a conquered nation with an impact on their self-esteem, which is also evident on the Czech side.

Respondents compared the approach to the life of both nationalities. While they admired contentment and composure of Czechs, Ukrainians are easy to ignite and excite for a thing. From the point of view of work morale and discipline, respondents clearly see more active and hardworking Ukrainians. On the other hand, Czechs have a greater order in matters, including work, which is also related to the ability to plan better and with their punctuality, which Ukrainians generally lack. However Ukrainians also criticize this virtue by stating that the Czechs do not like to change themselves and change anything of their established order.

\section{Unity of the Czech Republic and the division of Ukrainian culture}

The literature on the Ukrainian national minority states that the church is an important meeting place for Ukrainians in the Czech Republic and the opportunity to talk to compatriots. It is known that Ukrainians are a strong religious nation compared to Czechs, most of who profess to be atheists. Ukrainians appreciate the fact that both countries have Christian roots, culture and celebrate similar holidays, but respondents have different views on how to celebrate the main holidays in the Czech Republic. The Ukrainians were disappointed by the great holidays in the Czech Republic, which are accompanied by a large number of various customs in Ukraine. 
According to Ukrainians, Czech culture can be described as a whole and unified one, because most Czechs know the same songs, poems, have their literary authors and Czech customs, traditions do not differ much in individual regions. While Ukrainian literature, culture, and language bear the mark of Russian influence and thanks to the multinational situation within one state, Ukrainian cultural identity has only begun to form in recent decades.

\section{Primary education}

At first glance, the school system in Ukraine appears to be very similar to the Czech one. On the basis of respondents' testimonies, it can be said that the school system in Ukraine places much more demands on pupils. Pupils have to prepare for lessons for a few hours a day and many homework tasks are given to them. Pupils with experience with the education system in Ukraine are used to intensively learning and preparing for school. With the transition to the Czech Republic, most of them feel markedly easier learning in terms of curriculum and teaching methods. Pupils' parents are initially amazed that a pupil does not have to do so many homework assignments daily. However, they positively acknowledge that learning is more fun for children because they get less information by more entertaining methods.

The Ukrainian education system puts more emphasis on discipline of pupils in Ukraine who are obliged to show greater respect to their teachers. The teacher's position is still perceived as the main and unshakable authority. Therefore, it can also be said that Ukrainian pupils are more readily adaptable to other cultures and to other education systems, for their discipline and respectful attitude towards authorities.

In relation to Czech parents, Ukrainian parents are used to more intensive preparation of their children for school and in connection with this they perceive that children in the Czech Republic are more independent. Ukrainian parents control their children more and emphasize the need to study, for example, by the words of one respondent: "I always say to my daughter, no matter, what's the school, but it depends on the pupil, what you have in your mind."

\section{Secondary and tertiary education}

To the question of secondary education system Ukrainians note that, in relation to the Czech Republic, where after schooling, pupils decide between 
schools with GCSE or without GCSE, every Ukrainian receives a GCSE. This fact is the legacy of the Soviet system, which tried to bring every citizen to graduation.

In view of the fact that many secondary schools and apprenticeships have been abolished after Ukraine's declaration of independence, pupils often heading to universities after the end of general education. According to respondents, most of the Ukrainian population disposes of completed university education. In connection with that, people with titles in Ukraine are not so honoured and do not use titles. While in the Czech Republic Ukrainians perceive greater respect for Czechs with a university degree. It can be said that possessing a diploma is part of a good upbringing in Ukraine, and it shows a certain effort and perseverance of the Ukrainians to succeed.

As regards tertiary education there is a great difference between applicability of the Czech and Ukrainian diploma. While a diploma obtained at a Czech university is recognized throughout the European Union, diplomas from Ukrainian universities must be subjected to recognition in the EU, and Ukrainians must prove that they have the necessary education, knowledge and ability.

In the Ukrainian education system, respondents condemn the presence of corruption. That is why Ukrainians positively evaluates the Czech system, where bribery is almost non-existent and all students have the same chances of success. According to the pupils' parents, this habit of taking bribes is so strong and widespread in all areas of life that they do not believe in any change. According to respondents, many of their acquaintances are relocating their families also because of dissatisfaction with this system.

\section{Conclusion}

Our research suggests main conclusion both nations, cultures, mentality have many of the same features from history and similarities in language, culture and values. However, on closer inspection, we observe many nuances that distinguish Ukrainians and Czechs. Whether, it is the political and economic situation, the typical character or the state of education of both countries including attitudes to education.

Ukrainians bring positive values, which are hard work, diligence, effort, purposefulness, place great emphasis on education and strive for a better future for their children. They are also making great efforts to integrate into Czech society. As there is a trend that Ukrainians are increasingly settling 
in the Czech Republic, we have opportunity to better mutual understanding within the Czech-Ukrainian relations in the Czech Republic.

From the above outputs of Ukrainians can be concluded that their presence in the Czech Republic and continuing migration to this country are a great benefit for Czech society.

\section{Acknowledgement}

This paper has been funded by IGA project of Palacký University Olomouc: Aspects of the school and off school environment affecting the formation of the value of education of pupils and students in a different socio-cultural environment. IGA_PdF_2019 016.

\section{Bibliography}

Český statistický úřad. R04 Cizinci v ČR podle státního občanství v letech 1994-2018 (k 31. 12.) https://www.czso.cz/csu/cizinci/4-ciz_pocet_cizincu (18. 05.2019).

Drbohlav, D. ed. 2015. Ukrajinská pracovní migrace v Česku. Migrace - remitence - rozvoj. Praha: Univerzita Karlova, nakladatelství Karolinum.

Göbelová, T. 2015. Profesní hodnoty a etické principy v práci učitele. Ostrava: Ostravská univerzita v Ostravě, Pedagogická fakulta.

Montoussé, M. and Renouard, G. 2005. Přehled sociologie. Praha: Portál.

Nešpor, Z. 2017. Sociologická encyklopedie. https://encyklopedie.soc.cas. cz/w/Kultura (9.05.2019).

Průcha, J., Walterová, E. and Mareš, J. 2003. Pedagogický slovník. Praha: Portál.

Strauss, A. and Corbin, J. 1999. Základy kvalitativního výzkumu. Boskovice: Albert

Švaříček, R. and Šed’ová, K. 2007. Kvalitativní výzkum v pedagogických vědách. Praha: Portál.

Uherek, Z. 2004. Migrace do České republiky, sociální integrace a lokální společnosti v zemích pưvodu. Praha: Etnologický ústav Akademie věd České republiky. 


\section{The Czech Republic through the eyes of Ukrainians}

Abstract: In the paper, the perspective is presented of Ukrainians living in the Czech Republic on the selected aspects of local life. The research goal is to find out how the Ukrainians perceive life in the Czech Republic, Czech culture and education and what they see as differences and similarities of both cultures and ways of education. It is pointed out that the research includes the subjective experience, attitudes and opinions of individual respondents. Therefore, it does not represent the entire Ukrainian national minority living in the Czech Republic.

The research sample consisted of two groups of respondents who had the following composition: the first group included eight respondents who were Ukrainians with permanent residence in the Czech Republic, living in the Czech Republic for more than ten years; in the second group, seven Ukrainian learners were interviewed, who were educated in schools in the Czech Republic, and their parents. In the research, a qualitative design was chosen, namely the method of semi-structured interview with respondents. The analysis of the obtained data was performed by open and then axial and selective coding.

Keywords: Ukrainians, Czech Republic, culture, education, intercultural education

Translated by Pavlína Kobzová 